\title{
The gaudryceratid ammonoids from the Upper Cretaceous of the James Ross Basin, Antarctica
}

María E. Raffi, Eduardo B. Olivero, and Florencia N. Milanese

Acta Palaeontologica Polonica 64 (3), 2019: 523-542 doi:https://doi.org/10.4202/app.00560.2018

We describe new material of the subfamily Gaudryceratinae in Antarctica, including five new species: Gaudryceras submurdochi Raffi and Olivero sp. nov., Anagaudryceras calabozoi Raffi and Olivero sp. nov., Anagaudryceras subcompressum Raffi and Olivero sp. nov., Anagaudryceras sanctuarium Raffi and Olivero sp. nov., and Zelandites pujatoi Raffi and Olivero sp. nov., recorded in Santonian to Maastrichtian deposits of the James Ross Basin. The early to mid-Campanian A. calabozoi Raffi and Olivero sp. nov. exhibits a clear dimorphism, expressed by marked differences in the ornament of the adult body chamber. Contrary to the scarcity of representative members of the subfamily Gaudryceratinae in the Upper Cretaceous of other localities in the Southern Hemisphere, the Antarctic record reveals high abundance and diversity of 15 species and three genera in total. This highly diversified record of gaudryceratins is only comparable with the Santonian-Maastrichtian Gaudryceratinae of Hokkaido, Japan and Sakhalin, Russia, which yields a large number of species of Anagaudryceras, Gaudryceras, and Zelandites. The reasons for a similar, highly diversified record of the Gaudryceratinae in these distant and geographically nearly antipodal regions are not clear, but we argue that they probably reflect a similar paleoecological control.

Key words: Ammonoidea, Phylloceratida, Gaudryceratinae, Lytoceratoidea, Cretaceous, Antarctica.

María E. Raffi [eugeniaraffi@gmail.com] and Eduardo. B. Olivero [emolivero@gmail.com

], Centro Austral de Investigaciones Científicas (CADIC), CONICET, Bernardo

Houssay 200, CP9410, Ushuaia, Argentina and Instituto de Ciencias Polares, Ambiente y Recursos Naturales, Universidad Nacional de Tierra del Fuego, Ushuaia, Argentina. Florencia N. Milanese [ fnmilanese@gmail.com], Universidad de Buenos Aires, Facultad de Ciencias Exactas y Naturales, Departamento de Cs. Geológicas, Instituto de Geociencias Básicas, Aplicadas y Ambientales de Buenos Aires (IGEBA), CONICET, Buenos Aires, Argentina. 
This is an open-access article distributed under the terms of the Creative Commons

Attribution License (for details please see creativecommons.org), which permits unrestricted use, distribution, and reproduction in any medium, provided the original author and source are credited.

\author{
FoF Full text $(1,034.6 \mathrm{kB})$ । \\ Farif Supplementary file $(460.1 \mathrm{kB})$
}

